\title{
The human nucleolus organizer regions
}

\author{
Joseph G. Gall \\ Department of Embryology, Carnegie Institution for Science, Baltimore, Maryland 21218, USA
}

\begin{abstract}
Although the nucleolus was first described in the early $19^{\text {th }}$ century from both animal and plant cells, human nucleoli and particularly the five human nucleolus organizers have not been well characterized. In this issue of Genes \& Development, van Sluis and colleagues (pp. 1688-1701) present a detailed molecular analysis of these organizers, which occur on the short arms of five human chromosomes. The near identity of these arms suggests extensive interchromosomal exchange during evolutionary history.
\end{abstract}

The nucleolus is the most obvious component of the interphase nucleus. It is evident without staining or phase contrast and so was described in the early $19^{\text {th }}$ century, decades before the discovery of chromosomes. A lengthy review published in 1898 (Montgomery 1898) listed over 300 references! Nevertheless, the fact that the nucleolus is attached at a specific locus on a chromosome was not recognized until Barbara McClintock's (1934) seminal paper describing the maize nucleolus organizer (NO). Ordinarily, the nucleolus disappears from early prophase nuclei before the chromosomes become evident, but during meiotic prophase in maize (and other organisms), the nucleolus remains intact and is clearly attached at a specific locus on one chromosome. Still more decades passed before it was shown that the organizer contains the genes coding for ribosomal RNA and that the nucleolus is the site for storage and processing of the ribosomal RNA that eventually ends up in the cytoplasm (National Cancer Institute 1965). Many of these important insights came from cytological and molecular studies on Drosophila and the frog Xenopus, each of which has a single NO. Humans, by contrast, have five NOs on five separate chromosomes, complicating both the genetic and cytological analysis of the human ribosomal genes.

The five chromosomes with NOs are similar in one respect: The NOs are on the short arm, which is essentially identical in overall organization on all five chromosomes. This identity makes it difficult or impossible to study the NO in cells with the normal or near normal chromosome complement. Accordingly, McStay and colleagues (van

[Keywords: acrocentric chromosome; nucleolar organizer regions; ribosomal DNA]

Corresponding author: gall@carnegiescience.edu

Article is online at http://www.genesdev.org/cgi/doi/10.1101/gad.334748. 119.
Sluis et al. 2019) studied each of the five chromosomes after they had been introduced separately into the mouse A9 cell line. Although the human chromosomes were transcriptionally silent in the hybrid cell lines, they could be reactivated by transfecting the cells with an expression plasmid that encodes human TAF1A-D. With this system, the authors could thus examine the structure and activity of each NO separately.

In the region next to the centromere, each short arm consists of a short proximal junction sequence, a long rDNA array containing up to $6 \mathrm{Mb}$ of repeated sequences, a short distal junction sequence, and a block of satellite DNA consisting of a 48-bp repeat (see Fig. 1A in van Sluis et al. 2019). Their sequencing results confirm the near identity of the short arms of these five chromosomes. The simplest interpretation of these data is that numerous interchromosomal exchanges have taken place in the past and undoubtedly continue to do so.

The distal junction region is of special interest. Several years ago, the McStay group (Floutsakou et al. 2013) demonstrated the existence of a long noncoding transcript whose sequence corresponded to sequences in the distal junction region of the five acrocentric arms. However, because of sequence identity in these regions, it was not possible to know which chromosomes produced the transcripts. They now demonstrate that distal junction (DJ) transcripts are produced by each of the five acrocentric chromosomes contained in the separate mouse A9 cell lines. The data include both molecular analysis and in situ hybridization images of very high quality. An interesting feature of the hybridization images is the localization of the DJ transcripts in a few discrete foci near the nucleoli. These transcripts are noncoding, and so their functional significance remains to be determined.

This manuscript also includes molecular information on the homologous regions of the chimpanzee. The overall organization of the short arms is quite similar to that of the human, with the exception that the rDNA repeats are oriented in the opposite direction; that is, the rDNA is transcribed toward the telomere in the chimpanzee but toward the centromere in the human.

(C) 2019 Gall This article is distributed exclusively by Cold Spring Harbor Laboratory Press for the first six months after the full-issue publication date (see http://genesdev.cshlp.org/site/misc/terms.xhtml). After six months, it is available under a Creative Commons License (AttributionNonCommercial 4.0 International), as described at http://creativecommons.org/licenses/by-nc/4.0/. 
This study is important for several reasons. First, it supplies detailed sequence analysis for the short arms of the five chromosomes that contain $\mathrm{rDNA}$, sequence data that have been missing for a long time from the human genome annotation. As suspected, these arms are essentially identical to each other, presumably because they are subject to frequent interchromosomal exchanges. Second, it provides convincing evidence that a long noncoding transcript is produced from these short arms. The function of this transcript is not known, but its close physical association with the nucleolus raises the interesting prospect that it plays some role related to the transcription and/ or processing of the rDNA itself. Finally, by including comparable data from the chimpanzee, this study confirms that the detailed organization of the rDNA has remained stable over a relatively long evolutionary time scale. In summary, this study from van Sluis et al. (2019) provides an important overview of the human nucleolus organizer regions and a starting point for future investigations of their central role in cell metabolism.

\section{References}

Floutsakou I, Agrawal S, Nguyen TT, Seoighe C, Ganley AR, McStay B. 2013. The shared genomic architecture of human nucleolar organizer regions. Genome Res 23: 2003-2012. doi:10.1101/gr.157941.113

McClintock B. 1934. The relation of a particular chromosomal element to the development of the nucleoli in Zea mays. Z Zellforsch mikrosk Anat 21: 294-328.

Montgomery TH. 1898. Comparative cytological studies, with especial regard to the morphology of the nucleolus. J Morphol 15: 265-582. doi:10.1002/jmor.1050150204

National Cancer Institute. 1965. International symposium on the nucleolus, its structure and function (ed. Vincent WS, Miller OL), monograph 23. National Cancer Institute, Bethesda, Maryland.

van Sluis M, Ó Gailín M, McCarter JGW, Mangan H, Grob A, McStay B. 2019. Human NORs, comprising rDNA arrays and functionally conserved distal elements, are located within dynamic chromosomal regions. Genes Dev (this issue). doi:10.1101/gad.331892.119 


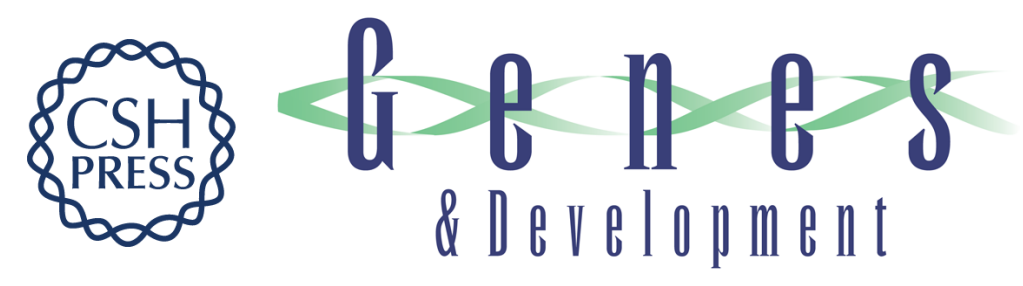

\section{The human nucleolus organizer regions}

Joseph G. Gall

Genes Dev. 2019, 33:

Access the most recent version at doi:10.1101/gad.334748.119

Related Content Human NORs, comprising rDNA arrays and functionally conserved distal elements, are located within dynamic chromosomal regions

Marjolein van Sluis, Michael Ó Gailín, Joseph G.W. McCarter, et al.

Genes Dev. December , 2019 33: 1688-1701

References This article cites 4 articles, 2 of which can be accessed free at:

http://genesdev.cshlp.org/content/33/23-24/1617.full.html\#ref-list-1

Articles cited in:

http://genesdev.cshlp.org/content/33/23-24/1617.full.html\#related-urls

Creative This article is distributed exclusively by Cold Spring Harbor Laboratory Press for the first Commons License six months after the full-issue publication date (see http://genesdev.cshlp.org/site/misc/terms.xhtml). After six months, it is available under a Creative Commons License (Attribution-NonCommercial 4.0 International), as described at http://creativecommons.org/licenses/by-nc/4.0/.

Email Alerting Receive free email alerts when new articles cite this article - sign up in the box at the top Service right corner of the article or click here.

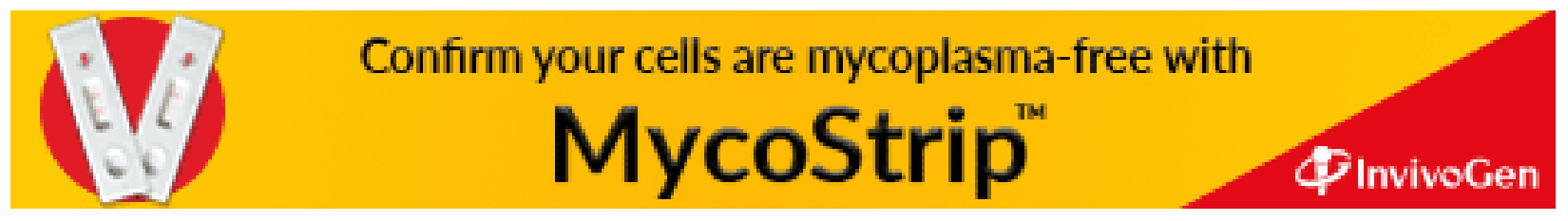

